\title{
Evaluation of the vertical alterations of the upper second molars after the alignment and leveling phase using the MBT technique
}

\author{
Alael Barreiro Fernandes de Paiva Lino¹, Julio Wilson Vigorito²
}

Objective: This study aimed at comparing the distocervical angulations of upper second molars crowns of groups with normal occlusion and with Angle Class I and II malocclusions. Additionally, it aimed to analyze the changes occurring after alignment and leveling performed with MBT technique.

Methods: The sample of normal occlusions comprised 32 lateral teleradiographs, while the sample of malocclusions comprised 38 initial and post-leveling lateral teleradiographs.

Results: The results did not show statistically significant differences between morphological characteristics of the normal occlusion group and the malocclusion group. On the other hand, after alignment and leveling, statistically significant reduction was observed in distocervical inclinations with extrusion of the distal portion of upper second molars.

Keywords: Dental occlusion. Design of orthodontic appliances. Radiography. Corrective orthodontics.

Objetivo: a proposta do presente trabalho foi comparar as angulações distocervicais das coroas dos segundos molares superiores de um grupo com oclusão normal e outro composto de más oclusões de Classes I e II de Angle, e analisar as modificações ocorridas após o alinhamento e nivelamento com a técnica MBT.

Métodos: a amostra de oclusão normal foi composta por 32 telerradiografias laterais; e a amostra de má oclusão constituiu-se de 38 telerradiografias laterais iniciais e pós-nivelamento.

Resultados: os resultados não mostraram diferença estatisticamente significativa entre as características morfológicas dos grupos com oclusão normal e com má oclusão; porém, após o alinhamento e nivelamento, observamos redução estatisticamente significativa nas inclinações distocervicais, com extrusão da porção distal dos segundos molares superiores.

Palavras-chave: Oclusão dentária. Desenho de aparelho ortodôntico. Radiografia. Ortodontia corretiva.

${ }^{1}$ Resident of Orthodontics, School of Dentistry - University of São Paulo (USP). ${ }^{2}$ Full Professor of Orthodontics, School of Dentistry - University of São Paulo (USP).

" The patient displayed in this article previously approved the use of her facial and intraoral photographs.

" The authors report no commercial, proprietary or financial interest in the products or companies described in this article.
How to cite this article: Lino ABFP, Vigorito JW. Evaluation of the vertical alterations of the upper second molars after the alignment and leveling phase using the MBT technique. Dental Press J Orthod. 2013 Sept-Oct;18(5):115-20.

Submitted: December 11, 2009 - Revised and accepted: December 29, 2010

Contact address: Alael Barreiro Fernandes de Paiva Lino Av. Professor Lineu Prestes, 2.227, Cidade Universitária CEP: 05.508-000 - São Paulo - SP - Brazil

E-mail: alael@usp.br 


\section{INTRODUCTION}

The University of São Paulo College of Dentistry postgraduate program offers a course that provides clinical practice of research about MBT pre-adjusted appliances. It aims to qualify students to perform the Straight-Wire MBT technique on the treatment of malocclusions, with or without teeth extractions, based on the researches developed in the program and the material that has been documented. By means of observing the clinical results and the elements of diagnosis obtained after orthodontic alignment and leveling of treated groups, it was noticed, in some cases, premature contacts and occlusal interferences on the region of second molars. This fact encouraged the study of the characteristics of this area and any potential alterations occurring after dental alignment and leveling.

MBT appliances were assembled according to what the technique suggests, ${ }^{11}$ regarding height and angulation of the orthodontic accessories. These variables are described in the orthodontic literature with the purpose of maintaining and preparing both functional characteristics and anchorage, in order to obtain normal occlusion free of occlusal interferences. Teeth angulations are obtained by means of changing the brackets position or inserting second-order bends on stainless steel arches ${ }^{12}$ on the upper second molars. These variations aim to control the anchorage, maintain the initial tooth position and prevent occlusal interferences on mandibular movement. ${ }^{6,10,12,14,16}$

In order to prepare the anchorage, a previous study ${ }^{12}$ determine that the upper second molar movement be performed with cervicodistal angulation of $20^{\circ}$, with the orthodontic arch in $10^{\circ}$ of angulation on this tooth's region. Another possibility to perform angulation on the upper second molar is inserting the accessory with angulation of 15 degrees $^{14}$ or bonding the tube on the same plane after basic leveling of first molars to upper canines..$^{10}$ On the other hand, some authors recommend inclusion on the mechanics of second molars in cases of extraction of four first premolars, third molars or in cases of buccolingual crossing. In normal clinical situations, it is necessary to await the natural establishment of the occlusion. ${ }^{18}$ In 1972, after studying 120 models of individuals with characteristics of normal occlusion, Andrews ${ }^{1}$ presented an article suggesting six keys of normal occlusion that should be obtained after orthodontic therapy. These occlusal characteristics served as a basis for introducing the Straight-Wire appliance. This appliance has on its design, brackets slots with preangulation following the mesiodistal angulation of the vestibular surface. In relation to the upper second molar, Andrews' findings showed, on average, a mesial angulation of the clinical crown in 0.39 degrees. ${ }^{4}$ The literature about preadjusted appliances proposes several values such as 5 degrees, ${ }^{11} 3$ degrees, ${ }^{7} 4.09$ degrees, ${ }^{17} 0$ degrees, ${ }^{15}-0.30$ degrees ${ }^{17}$ and -5 degrees. ${ }^{5}$ In addition to angulation, the height in which the orthodontic accessories are positioned on the teeth is a recurrent variable in orthodontic clinics.

Vigorito $^{16}$ mentions in his book that the occlusalcervical height of the bracket on the upper second molar must be $0.5 \mathrm{~mm}$ lower than that on the upper first molar, with $0^{\circ}$ of angulation and insertion of caudal angle on the orthodontic arch on the upper second molar region. As for the MBT technique, ${ }^{11}$ it is recommended to use the accessories installation table in which it is stated that the mean height for the upper second molar is $2.0 \mathrm{~mm}$ and $3.0 \mathrm{~mm}$ for the first molars. As verified in the studies previously mentioned, there are different prescriptions concerning the angulation to be expressed on the upper second molar, varying from the MBT prescription, that indicates $5^{\circ}$ of mesial angulation, to the researches indicating that the upper second molars present and must keep, during and after the orthodontic therapy, a cervicodistal angulation. ${ }^{5,6,9,10,12,14,16}$ The present study aimed to compare the characteristics of mesiodistal angulation and vertical positioning 9 of the upper second molars between the normal occlusion group, which had the control function, and the malocclusion group. In addition, it aimed at verifying the alterations occurring after alignment and leveling performed with MBT preadjusted appliances. Based on the aforementioned objectives, this study proposed:

1. To verify potential differences in vertical and angular positions of the upper second molars, observed in lateral teleradiographs, by means of comparing Class I and II malocclusion to normal occlusion.

2. To evaluate, through cephalograms, the position of the upper second molars comparing initial and final phases of alignment and leveling performed with MBT technique. 


\section{MATERIAL AND METHODS}

\section{Sample}

The control group consisted of a normal occlusion sample comprising 32 lateral teleradiographs obtained from Brazilian, leukoderma individuals, 16 of which were males and 16 females, aged between 12 and 17 years and 1 month old, with permanent dentition classified as normal dental occlusion, and with no previous orthodontic treatment. The malocclusion sample comprised 76 lateral teleradiographs obtained from 38 Brazilian, leukoderma patients of both genders, with permanent teeth and Angle Class I and Class II malocclusions, under treatment at, Corrective Orthodontic MBT preadjusted Clinic, at the University of São Paulo (USP) College of Dentistry. The radiographs were divided into two groups: $\mathrm{T}_{1} \mathrm{r}$ which corresponds to initial teleradiographs and $\mathrm{T}_{2} \mathrm{r}$ which corresponds to the final phases of alignment and leveling.

\section{Appliance assemblage}

MBT appliances were assembled according to what the technique suggests, ${ }^{11}$ regarding height and angulation of the orthodontic accessories in the region of second molars.

\section{Image digitizing}

\section{Radiograph digitizing}

The radiographs were scanned and the images were imported by the Radiocef Studio 4.0 software,

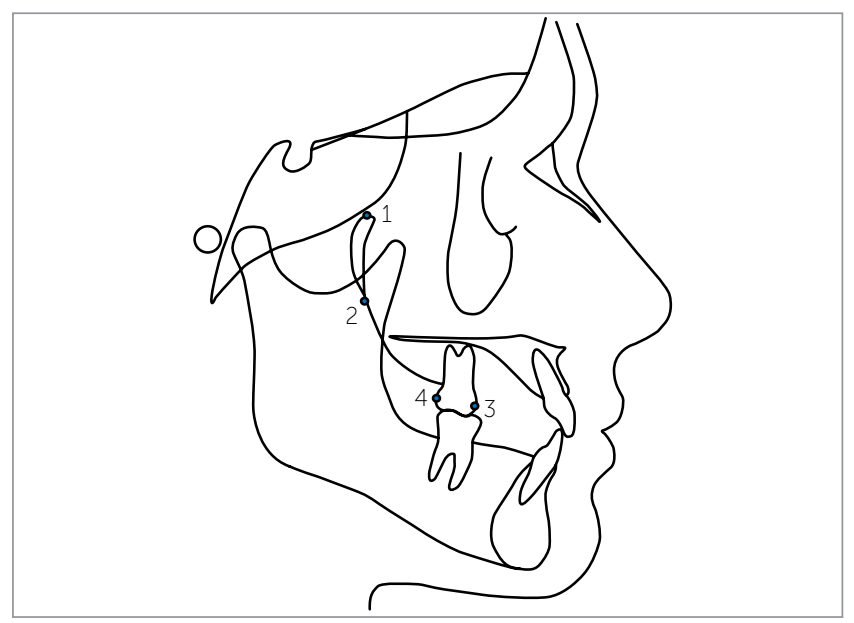

Figure 1 - Cephalometric landmarks demarcated on the lateral teleradiograph. 1) PTMs, 2) PTM, 3) M7, 4) D7. kindly granted by Radio Memory Ltda (www.radiomemory.com.br). On this software, cephalometric landmarks were marked and the magnitudes, necessary for this research, were defined.

\section{Landmarks determination}

Landmarks were directly marked on the images of the structures of interest. The landmarks used were:

\section{Cephalometric landmarks (Fig 1)}

" Landmark D7: Most distal landmark of the upper second molar image.

" Landmark M7: Most mesial landmark of the upper second molar image.

" Landmark PTMs: Most upper point of the pterygomaxillary fossa.

" Landmark PTM: Most lower point of the pterygomaxillary fossa which corresponds to the pterygomaxillary fissure.

\section{Determination of the lines of orientation.}

Radiographic lines and planes (Fig 2)

"Pterygomaxillary fossa long axis (vertical PTM): line that joins landmarks PTMs to PTM.

" Perpendicular to the long axis of the pterygomaxillary fossa (horizontal PTM): Line traced from the landmark PTM perpendicular to the pterygomaxillary fossa long axis.

» D7-horizontal PTM: Orthogonal to horizontal line PTM up to landmark D7.

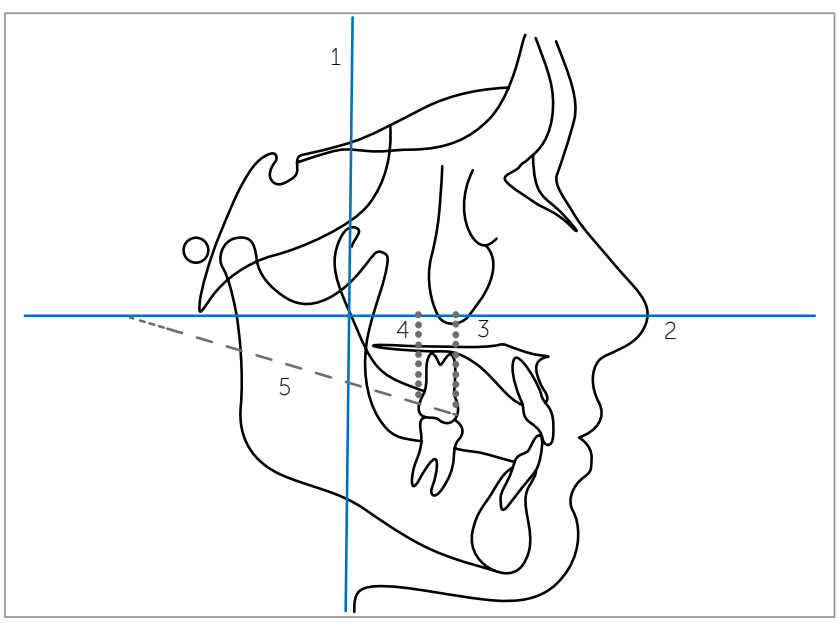

Figure 2 - Lines demarcated on the lateral teleradiograph. 1) Vertical line PTM. 2) Horizontal line PTM. 3) M7-Horizontal line PTM. 4) D7-Horizontal line PTM. 5) md7 line. 
» M7-horizontal PTM: Orthogonal to horizontal line PTM between landmark M7.

" Mesio-distal line of the upper second molar (line md7): Line that joins landmarks M7 to D7.

\subsection{Determining the magnitudes.}

\section{Radiographic magnitudes (Fig 3)}

» D7-horizontal PTM Height (distal height): Orthogonal distance between landmark D7 with horizontal line PTM.

" M7-horizontal PTM Height (mesial height): Orthogonal distance between landmark M7 with horizontal line PTM.

" md7 - horizontal PTM Angle line (cervicodistal angle): Formed by intersection of horizontal line PTM with line md7.

\section{Statistical methods}

Descriptive statistics were obtained by means of verifying both mean and standard deviation of all magnitudes studied. Normal distribution of data was assessed through Shapiro-Wilks test. The means of the magnitudes obtained from the teleradiographs and after alignment and leveling were compared through one-way ANOVA test complemented by Tukey test at $5 \%$. To verify the method error, the samples were reevaluated and the values obtained from the second

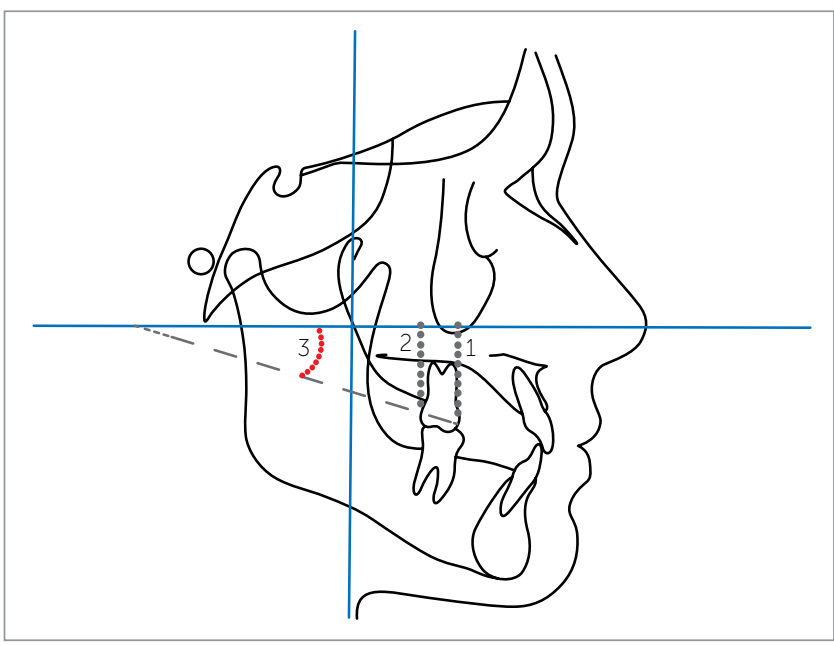

Figure 3 - Linear and angular magnitudes determined no the lateral telera diograph. 1) mesial height. 2) distal height. 3) cervicodistal angle. measurement process were submitted to $t$ test for systematic error verification, while the Dahlberg method was used for random error verification.

\section{RESULTS}

The descriptive statistics obtained from the teleradiographs are presented in Table 1.

Comparisons between the means of the linear magnitudes observed in the teleradiographs are shown in Table 2.

Comparisons between the means of the angular magnitudes observed in the teleradiographs are presented in Table 3 .

\section{DISCUSSION}

Table 1 - Descriptive statistics of cephalometric magnitudes values.

\begin{tabular}{lll}
\hline & Mean & SD \\
\hline Normal occlusion distal height & 25.02 & 3.21 \\
\hline Normal occlusion mesial height & 29.95 & 3.11 \\
\hline Initial malocclusion distal height & 26.32 & 3.96 \\
\hline Initial malocclusion mesial height & 31.26 & 4.24 \\
\hline Post-leveling malocclusion distal height & 30.32 & 4.24 \\
\hline Post-leveling malocclusion mesial height & 32.52 & 4.27 \\
\hline Normal occlusion cervicodistal angulation & 26.24 & 5.43 \\
\hline Initial malocclusion cervicodistal angulation & 25.85 & 6.82 \\
\hline Post-leveling malocclusion cervicodistal angulation & 11.93 & 6.44 \\
\hline
\end{tabular}

Table 2 - Comparison between the means of linear magnitudes observed in the teleradiograph by one-way ANOVA test complemented by Tukey at $5 \%$

\begin{tabular}{lllllll}
\hline & A & B & C & D & $E$ & $F$ \\
A & - & $* *$ & $*$ & $* *$ & $* *$ & $* *$ \\
B & $*$ & - & $* *$ & $*$ & $*$ & $*$ \\
C & $*$ & $*$ & - & $* *$ & $* *$ & $* *$ \\
$D$ & $*$ & $*$ & $*$ & - & $*$ & $*$ \\
E & $*$ & $*$ & $*$ & $*$ & - & $* *$ \\
\hline
\end{tabular}

A) Normal occlusion distal height. B) Normal occlusion mesial height. C) Initial malocclusion distal height. D) Initial malocclusion mesial height. E) Postleveling malocclusion distal height. F) Post-leveling malocclusion mesial height *: non-significant difference. **: significant difference.

Table 3 - Comparison between the means of angular magnitudes observed in the teleradiograph by one-way ANOVA test complemented by Tukey at $5 \%$.

\begin{tabular}{cccc}
\hline & G & H & I \\
\hline$G$ & - & $*$ & $* *$ \\
$H$ & $*$ & - & $* *$ \\
\hline
\end{tabular}

G) Normal occlusion cervicodistal angle. H) Malocclusion initial time cervicodistal angle. I) Post-leveling malocclusion cervicodistal angle. *) non-significant difference. ${ }^{* *}$ ) significant difference. 
Systematic error evaluation demonstrated reproducibility ( $\mathrm{p}<0.01)$, while random error variability ranged from 0.62 for mesial height to 0.70 for distal height of the normal occlusion group. The results of the method error validated the results obtained from the analysis of cephalometric magnitudes, thus, supporting discussion about the clinical implications of installing orthodontic accessories on the upper second molars. Distocervical angulation of the upper second molars is a characteristic found in individuals with normal occlusion (Fig 4). ${ }^{6,9}$ According to the results of this research, it was possible to observe that the group with malocclusion showed the same characteristics regarding the vertical positioning of upper second molars in relation to the control group (Fig 5). After alignment and leveling, the characteristics observed in the second molars were significantly altered (Fig 6). The cervicodistal angle of the upper second molar was significantly reduced from $25.85^{\circ}$ to $11.93^{\circ}$ due to extrusion of the distal surface and maintenance of the vertical position of the mesial surface. Significant alteration was observed in the vertical positioning of the upper second molar distal surface. At the initial phase, it was $26.32 \mathrm{~mm}$, while after leveling it was $30.32 \mathrm{~mm}$ On the other hand, the vertical position of the mesial face did not show significant differences after alignment. Relevant literature provides researches that indicate lower angulations on upper second molars than what has been suggested in this study. ${ }^{4,7,11,15,17}$
We also found authors indicating negative inclination $^{6,8,9,10,12,14}$ to preserve and prepare the anchorage during orthodontic mechanics as well as keep the functional position of the upper second molar aiming to avoid premature contacts and interference in mandibular eccentric movements.

Thus, we can conclude that angular alterations performed on the upper second molars for preparing and maintaining the anchorage or for leveling and alignment, must be corrected in order to restore the characteristics of this region.

Additionally, the results obtained from this research demonstrate that the use of pre-adjusted accessories with MBT prescription significantly reduces mesiodistal angulation ${ }^{6,10}$ and changes the vertical positioning of the teeth observed in both normal occlusion and malocclusion groups. Aiming to minimize any possible errors while installing the accessories, this research carefully followed, by means of the suggested bonding table, the recommendations of the MTB technique. ${ }^{11}$

Clinically, the obtained results allow us to suggest that the accessory positioning should be performed on the second molar with disto-occlusal angle and with a height lower than that performed on the first molar. This way, extrusion would be controlled and angulation would be preserved. Furthermore, we observed the need of installing and modifying the accessories in order to determine disto-occlusal angulation around $5^{\circ}$. With such a prescription, the characteristics of both

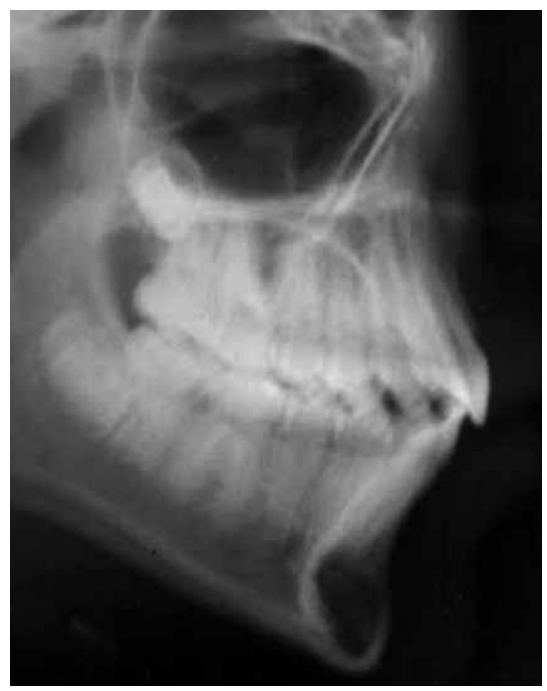

Figure 4 - Lateral teleradiograph - normal occlusion.

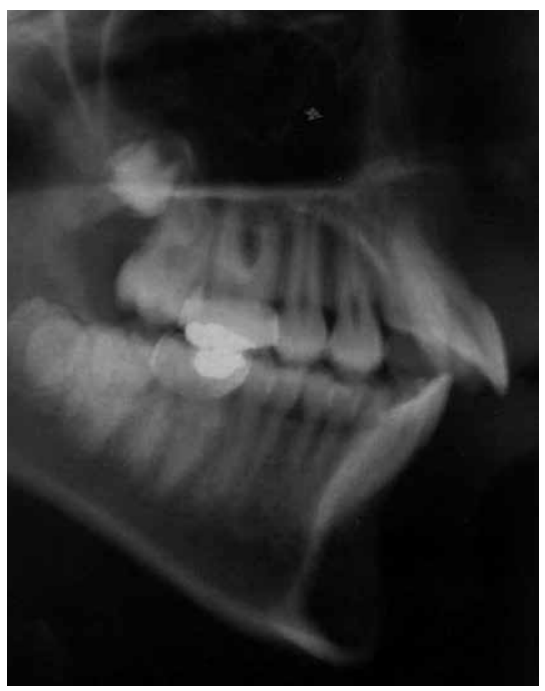

Figure 5 - Pre-treatment lateral teleradiograph of the malocclusion group

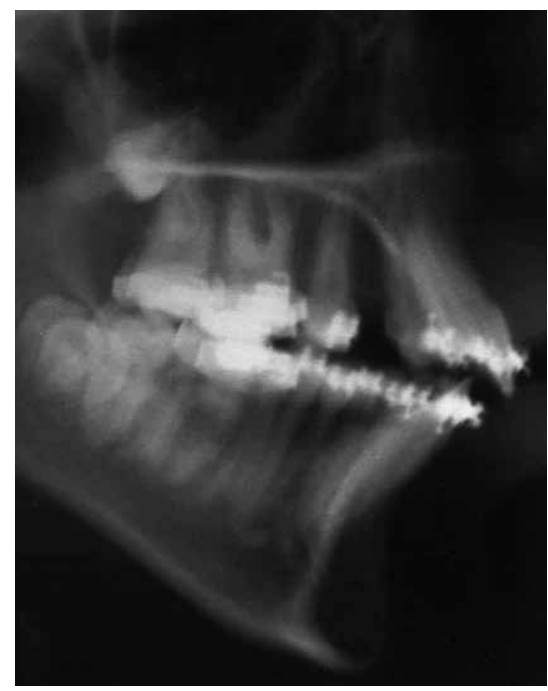

Figure 6 - Post-leveling lateral teleradiograph of the malocclusion group. 
position and angulation of the upper second molar would be preserved. We believe that further researches must be carried out in order to indicate modifications in the prescription of accessories for upper second molars and thus, keep the functional characteristics present in the region of these teeth, minimizing the risk of premature contacts and occlusal interferences as well as enabling vertical control to be managed.

\section{CONCLUSIONS}

1. No statistically significant differences were observed in the angular characteristics of the second molars when both the normal occlusion and the malocclusion groups were compared. The clinical crowns of the second molars are always angulated in distocervical direction.

2. The upper second molars presented differences in the angulation of the crowns when compared to the beginning and to the group of normal occlusion, with a decrease due to extrusion of the distal portion. Significant reduction of the mesiodistal angulation of upper second molars and extrusion of the distal portion were observed.
REFERENCES

1. Andrews LF. Six keys to normal occlusion Am J Orthod. 1972;62(2):296-309.

2. Andrews LF. Straight-wire appliance, explained and compared. J Clin Orthod, 1976:10(3):174-95

3. Andrews LF. Straight-wire appliance, origin, controversy, commentary. J Clin Orthod. 1976:10(2):99-114

4. Andrews LF. Straight-wire: the concept and appliance. 1 $^{\text {st }}$ ed. San Diego K-W; 1989.

5. Baptista JM. Ortodontia personalizada. 1a ed. São Paulo: Ed. Santos; 2004

6. Carvalho DS. Avaliação da posição morfo-funcional dos segundos molares permanentes superiores em pacientes: tratados ortodonticamente e dotados de oclusão normal [tese]. São Paulo (SP): Faculdade de Odontologia da USP; 1989

7. Currim S, Wadkar PV, Objective assessment of occlusal and coronal characteristics of untreated normals: a measurement study. Am J Orthod Dentofacial Orthop. 2004;125(5):582-8

8. Holdaway RA, Bracket angulation as applied to the edgewise appliance. Angle Orthod. 1952;22(4):227-326

9. Lino ABFP, Vigorito JW. Avaliação cefalométrica da posição vertical das faces mesial e distal dos segundos molares superiores em individuos com oclusão normal. In: Dominguez GC, organizador. Nova visão em ortodontia e ortopedia funcional dos maxilares. 1a ed. São Paulo: Ed. Santos; 2006. v. 1, p. 51-6.

10. Lino AP. Ortodontia corretiva técnica MD3. 1a ed. São Paulo: Artes Médicas; 2001

11. McLaughlin RP, Bennett JC, Trevisi HJ, Mecânica sistematizada de tratamento ortodôntico. 1a ed. São Paulo: Artes Médicas: 2004

12. Merrifield LL, The sequential directional force edgewise technique. In: Johnston LE Jr. New vistas in orthodontics. 1a ed. Philadelphia: Lea 8 Febiger; 1985.

13. Parker WS. Consideration of pure Begg technique. Angle Orthod 1969:39(1):1-10

14. Root TL. Level anchorage edgewise. In: Johnston LE Jr. New vistas in orthodontics. $1^{a}$ ed. Philadelphia: Lea \& Febiger; 1985.

15. Roth RH. Functional occlusion for the orthodontist - Part I. J Clin Orthod. 1981;15(1):32-51

16. Vigorito JW. Ortodontia clínica, diagnóstico e terapêutica. 1a ed. São Paulo: Santa Madonna; 2004

17. Watanabe K, Koga M. A morphometric study with setup models for bracket design. Angle Orthod. 2001;71(6):499-511.

18. Zielinsky L. El plan de tratamiento ortodoncico y la oclusión como objetivo. 1a Parte. Ortodoncia,1978:33(88):137-47. 